\title{
Constitutional Aspects of Physician-Assisted Suicide After Lee v. Oregon
}

Simon Canick

Mitchelll Hamline School of Law, simon.canick@mitchellhamline.edu

Publication Information

23 American Journal of Law \& Medicine 69 (1997)

\section{Repository Citation}

Canick, Simon, "Constitutional Aspects of Physician-Assisted Suicide After Lee v. Oregon" (1997). Faculty Scholarship. Paper 150. http://open.mitchellhamline.edu/facsch/150 


\title{
Constitutional Aspects of Physician-Assisted Suicide After Lee v. Oregon
}

\begin{abstract}
On November 8, 1994, Oregon voters narrowly passed the highly controversial Death with Dignity Act (Measure 16), which marked the first time that physician-assisted suicide was explicitly legalized anywhere in the world. In Lee v. Oregon, a group of physicians, several terminally ill persons, a residential care facility, and individual operators of residential care facilities sought to enjoin enforcement of the new law, claiming various constitutional infirmities. The U.S. District Court for the District of Oregon enjoined enforcement of the law, acknowledging that it raised important constitutional issues including possible violations of the Equal Protection and Due Process Clauses of the Fourteenth Amendment. This note analyzes the impact of the Lee and the debate surrounding physician assisted suicide. Part II of this Note outlines several important ethical and legal arguments both in favor of, and opposed to, legalized assisted suicide. Part III discusses the cases that have reviewed laws prohibiting physician-assisted suicide. Part IV examines Measure 16 in detail, including a review of the safeguards drafted into the act. This Note continues with a discussion of the constitutional questions presented in Lee v. Oregon as traditionally analyzed and as treated by the court. This Note concludes that one may not properly infer a fundamental right to assisted suicide. In addition, the Equal Protection Clause does not prevent states from recognizing a patient's right to remove life-sustaining treatment and hydration, while prohibiting doctors from prescribing lethal medication to the terminally ill on request.
\end{abstract}

\section{Keywords}

Assisted suicide, constitutional law, Compassion in Dying, equal protection clause, liberty, terminal illness

\section{Disciplines}

Constitutional Law | Medical Jurisprudence 


\title{
Constitutional Aspects of Physician- Assisted Suicide After Lee v. Oregon
}

\author{
Simon M. Canick $\dagger$
}

Dying is personal. And it is profound. For many, the thought of an ignoble end, steeped in decay, is abhorrent. A quiet, proud death, bodily integrity intact, is a matter of extreme consequence.

-Justice William Brennan'

\section{INTRODUCTION}

Two recent circuit court decisions have reinvigorated the debate over the constitutional, practical and ethical ramifications of physician-assisted suicide. ${ }^{2}$ In Compassion in Dying v. Washington, the Ninth Circuit Court of Appeals held that a liberty interest exists in choosing the time and manner of one's death. ${ }^{3}$ The court found this right to outweigh all asserted state interests, and concluded that, with respect to competent, terminally ill adults, Washington's prohibition of assisted suicide violates the Due Process Clause of the U.S. Constitution. ${ }^{4}$ The ruling effectively strikes down laws against assisted suicide in all of the states in the Ninth Circuit. 5

In April 1996, in Quill v. Vacco, the Second Circuit Court of Appeals held that New York's prohibition of assisted suicide violates the U.S. Constitution's Equal

† B.A., 1992, Hamilton College; J.D. candidate, 1997, Boston University School of Law. The author would like to thank the incredible AJLM staff, his remarkably. supportive family, and wonderful friends, especially Molly, Lindsay, Jeremy, Josh, Ashley, Jeff, Courtney, and Brooks. Special thanks to Trey Anastasio and David Wilcox for keeping me in tune.

1 Cruzan v. Director, Missouri Dep't of Health, 497 U.S. 261, 310-11 (1990) (Brennan, J., dissenting).

2 For purposes of this Note, physician-assisted suicide "occurs when a physician facilitates a patient's death by providing the necessary means and/or information to enable the patient to perform the life-ending act." Council on Ethical \& Judicial Affairs, American Med. Ass'n, Decisions Near the End of Life, 267 JAMA 2229, 2229 (1992) [hereinafter Decisions]. (1996).

379 F.3d 790, 816 (9th Cir.), cert. granted sub nom. Washington v. Glucksberg, $117 \mathrm{~S}$. Ct. 37

4 See id. at 838; see also U.S. CONST. amend. XIV, $\$ 1$.

5 The Ninth Circuit includes the following states and territories: Alaska, Arizona, California, Guam, Hawaii, Idaho, Montana, Nevada, Oregon and Washington. 
Protection Clause. ${ }^{6}$ The court found that the law treated similarly situated groups dissimilarly by allowing the withdrawal of life-sustaining treatment even if that would result in death, but preventing physicians from prescribing lethal medication to other terminally ill people at their request. ${ }^{7}$ The U.S. Supreme Court agreed to review both decisions, and should issue its ruling this summer. ${ }^{8}$

The U.S. Supreme Court's review of Compassion in Dying and Quill has shared the "assisted suicide" spotlight of late. In Michigan prosecutors continue their crusade against Dr. Jack Kevorkian, trying him unsuccessfully for violations of state provisions against assisted suicide. 9 In Oregon, residents took a dramatic step in the opposite direction, voting to legalize physician-assisted suicide for competent, terminally ill people under certain circumstances. ${ }^{10}$

On November 8, 1994, Oregon voters narrowly passed the highly controversial Death with Dignity Act (Measure 16), fifty-two to forty-eight percent. ${ }^{11}$ Although physician-assisted suicide has received substantial attention in recent years, passage of the Oregon Measure marked the first time the practice had been explicitly legalized anywhere in the world.12 Measure 16, which allows physicians to prescribe a lethal dose of medication to terminally ill people under certain conditions, 13 temporarily shifted the debate over physician-assisted suicide. Rather than grapple with whether there exists a "right to die" protected by the U.S. Constitution, Measure 16 presented an opportunity to evaluate the novel concept of state-sanctioned assisted suicide. Subsequently, a U.S. district court considered traditional moral and legal arguments both for and against physician-assisted suicide in the context of a law allowing the practice. 14

Measure 16 authorizes a qualified patient to "request and obtain a prescription to end his or her life in a humane and dignified manner."15 Proponents of the law hoped that it would grant competent, terminally ill persons a way of ending their

680 F.3d 716, 727 (2d Cir.), cert. granted, 117 S. Ct. 36 (1996); see also U.S. ConsT. amend. XIV, $\$ 1$.

7 See Quill, 80 F.3d at 729.

8 See Vacco v. Quill, 117 S. Ct. 36, 36 (1996) (granting cert.); Washington v. Glucksberg, 117 S. Ct. 37, 37-38 (1996) (granting cert.).

${ }^{9}$ See Catherine L. Bjorck, Comment, Physician-Assisted Suicide: Whose Life Is it Anyway?, 47 SMU L. REV. 371, 379-82 (1994).

10 See Death with Dignity Act, 1995 Or. Laws ch. 3 (Initiative Measure No. 16) (codified at OR. REV. STAT. $\$ \$ 127.800-.995$ (1995)) [hereinafter Measure 16].

11 Id.; see also Art Caplan, Oregon Voters Open Can of Worms with Assisted-Death Bill, Hous. Chron., Dec. 10, 1994, at 3.

12 See Diane M. Gianelli, Assisted Suicide Showdown Headed to High Court?, AM. MED. News, Aug. 21, 1995, at 1, 1. Both euthanasia and assisted suicide are tolerated in the Netherlands, though not explicitly legal. See Paul J. van der Maas et al., Euthanasia and Other Medical Decisions Concerning the End of Life, 338 LANCET 669, 669 (1991). The Northern Territory of Australia recently legalized euthanasia and physician-assisted suicide. See, e.g., David C. Thomasma, When Physicians Choose to Participate in the Death of Their Patients: Ethics and Physician-Assisted Suicide, 24 J.L. MED. \& ETHICS 183, 188 (1996). However, on March 24, 1997, the Australian Senate voted to overturn the law. See Alan Thornhill, Australia Repeals Euthanasia Law, WASH. POST, Mar. 25, 1997, at A14. Four people committed suicide with assistance while the law was in effect. See id.

13 See Or. Rev. STAT. $\$ 127.800$ (1995).

14 See Lee v. Oregon, 891 F. Supp. 1491,1493 (D. Or. 1995).

15 OR. REV. STAT. ch. $127.800 \S 1.01(7)$. 
lives with dignity, free from suffering. ${ }^{16}$ The measure sought to achieve these goals by exempting doctors from punishment under the criminal statute outlawing assisted suicide. 17

In Lee $v$. Oregon, a group of physicians, several terminally ill persons, a residential care facility, and individual operators of residential care facilities sought to enjoin enforcement of the new law, claiming various constitutional infirmities. ${ }^{18}$ The plaintiffs initially claimed that Measure 16's classification of the "terminally ill" did not rationally relate to a legitimate state interest, and thus violated the Equal Protection Clause. 19 The plaintiffs also argued that Measure 16 deprived depressed, terminally ill people of their right to live, in violation of the Due Process Clause. ${ }^{20}$

The U.S. District Court for the District of Oregon enjoined enforcement of the law, acknowledging that it raised important constitutional issues including possible violations of the Equal Protection and Due Process Clauses of the Fourteenth Amendment. ${ }^{21}$ At a hearing on the merits, the court found that Measure 16 violated the Equal Protection Clause, but it failed to reach the due process issue.22 The court held that "Measure 16 withholds from terminally ill citizens the same protections from suicide the majority enjoys," but suggested that, with certain modifications, the act could pass constitutional muster. ${ }^{23}$

Although the Compassion in Dying decision, unless reversed on appeal to the U.S. Supreme Court, ${ }^{24}$ effectively grants terminally ill patients in Oregon the right to a physician's assistance in hastening their deaths, ${ }^{25}$ a detailed discussion of Lee $v$. Oregon remains vital. Other circuits may face challenges to laws legalizing physician-assisted suicide, and must therefore understand Lee. ${ }^{26}$

Part II of this Note outlines several important ethical and legal arguments both in favor of, and opposed to, legalized assisted suicide. Part III discusses the cases that have reviewed laws prohibiting physician-assisted suicide. Part IV examines Measure 16 in detail, including a review of the safeguards drafted into the act. This Note continues with a discussion of the constitutional questions presented in Lee $v$. Oregon as traditionally analyzed and as treated by the court.

${ }^{16}$ Cf. Charles H. Baron et al., A Model State Act to Authorize and Regulate Physician-Assisted Suicide, 33 HARV. J. ON LEGIS. 1, 4 (1996) (arguing that "it is reasonable to provide relief from suffering for patients who are dying or whose suffering is so severe that it is beyond their capacity to bear").

17 See OR. REV. STAT. $\$ 163.125$ (providing that "[c]riminal homicide constitutes manslaughter in the second degree when ... [a] person intentionally causes or aids another person to commit suicide").

18 See Lee v. Oregon, 869 F. Supp. 1491, 1493 (D. Or. 1994).

19 See Lee, 891 F. Supp. at 1431.

20 See Lee, 869 F. Supp. at 1497.

21 See id.

22 See Lee, 891 F. Supp. at 1437.

23 Id.

24 The Court heard oral arguments on January 8, 1997, and is expected to issue a ruling by midsummer. See Linda Greenhouse, Before the Court, the Sanctity of Life and of Death, N.Y. TIMES, Jan. 5, 1997, § 4, at 4 .

25 See Compassion in Dying v. Washington, 79 F.3d 791, 838 (9th Cir. 1996).

26 On February 27, 1997, the Ninth Circuit effectively reversed the district court's ruling in Lee v. Oregon. See Lee v. Oregon, 1997 WL 80783 (9th Cir. Feb. 27, 1997) The court held that the plaintiffs who challenged Measure 16 lacked standing. See id. at *6 (finding that "[n]one of the Plaintiffs can assert an 'injury in fact' resulting from the alleged . . . violations"). 
This Note concludes that one may not properly infer a fundamental right to assisted suicide. In addition, the Equal Protection Clause does not prevent states from recognizing a patient's right to remove life-sustaining treatment and hydration, while prohibiting doctors from prescribing lethal medication to the terminally ill on request. However, this Note also concludes that under relevant U.S. Supreme Court cases, the court in Lee $v$. Oregon erred by ruling that Measure 16 violated equal protection. Because the classification drawn in Measure 16 rationally relates to a legitimate state interest, there can be no violation of the Equal Protection Clause. If the courts eventually strike down Measure 16, this Note recommends that sponsors reintroduce a modified version of the law that satisfies the Lee court's concerns. Because the court based its judgment in part on the classification's perceived overinclusiveness, 27 it follows that a new act with tighter distinctions would pass equal protection analysis.

\section{ASSISTED SUICIDE}

Both suicide generally, and physician-assisted suicide specifically, have withstood rigorous historical scrutiny. ${ }^{28}$ The constitutional issues this Note addresses reflect significant moral, ethical, theological and practical concerns.

\section{A. Traditional arguments in Favor of Physician-Assisted Suicide}

The primary arguments in support of legalized physician-assisted suicide derive from familiar themes of dignity and personal autonomy. ${ }^{29}$ Technology which has extended the average life-span has also brought forth images of incapacitation, helplessness and suffering. ${ }^{30}$ Most Americans believe that terminally ill patients should be allowed to end their lives before they die of natural causes. ${ }^{31}$ The American Medical Association, while rejecting physician-assisted suicide, noted that physicians "demonstrate respect for human dignity when [they] acknowledge 'the freedom [of individuals] to make choices in accordance with their own values." 32 Despite objecting to suicide generally, many feel that assisted suicide presents a reasonable alternative to living with the perceived indignity and pain of terminal illness. ${ }^{33}$

Closely related to the idea that we should live and die with dignity is the celebrated concept of personal autonomy. As a popular notion, personal autonomy implies a certain latitude of self-determination, valued because "it permits people to

27 See Lee, 891 F. Supp. at 1437.

28 See Ezekiel J. Emanuel, Euthanasia: Historical, Ethical, and Empiric Perspectives, 154 ARCH. INTERN. MED. 1890, 1890-92 (1994).

29 See Decisions, supra note 2, at 2229.

30 See id.

31 See id; see also Emanuel, supra note 28, at 1898 (citing research demonstrating that $64 \%$ of the American public believes a physician should be allowed to administer a lethal injection to a terminally ill patient).

32 Decisions, supra note 2, at 2230 (quoting HASTINGS CTR., GUIDELINES ON THE TERMINATION of Life-Sustaining Treatment and Care of THE Dying (1987)).

33 The Model Penal Code, which categorizes assisted suicide as a second degree felony, seems to consider suffering as a mitigating factor. Commentary to section 201.5 states that although it might be easier to treat assisted suicide as murder, "where a husband yielded to the urging of his incurably sick wife to provide her with the means of self-destruction, motives are too often mixed ... to make the case compelling." MOdel PENAl CODE $\$ 201.5 \mathrm{cmt}$. 1 (Tentative Draft No. 9, 1959). 
form and live in accordance with their own conception of a good life, at least within the bounds of justice and consistent with others doing so as well." 34 Laws prohibiting assisted suicide curtail the freedom to make important choices about one's life. ${ }^{35}$

\section{B. Traditional ARguments Against Physician-AsSisted SuICIDE}

Those who oppose legalized assisted suicide in any form often rely on moral, religious and historical imperatives. Laws against suicide, although no longer in force in the United States, prevailed in English common law until 1961.36 English law "perceived suicide as an immoral, criminal offense against God and also against the King, who as a result thereof was deprived of one of his subjects." 37 The United States rejected laws against suicide in the mid-nineteenth century, ${ }^{38}$ although a large majority of states continue to criminalize aiding and abetting suicide. ${ }^{39}$

States continue to prohibit assisted suicide to protect the sanctity of human life. 40 In principle, "the interests in the sanctity of life that are represented by criminal homicide laws are threatened by one who expresses a willingness to participate in taking the life of another, even though the act may be accomplished with the consent, or at the request, of the suicide victim."41 These objections probably originated in religious doctrine. ${ }^{42}$

Some have argued that legalizing assisted suicide will make suicide a rational or reasonable alternative to life. One commentator presented the worst-case scenario:

In a suicide-permissive society plagued by shortages of various kinds and a growing population of 'nonproductive' people, how likely is it that an old or ill person will be encouraged to spare both herself and her family the agony of a slow decline, even though she would not have considered suicide on her own? ${ }^{43}$

34 Dan W. Brock, Voluntary Active Euthanasia, HASTINGS CTR. REP., Mar-Apr. 1992, at 10, 11.

35 But see Emanuel, supra note 28, at 1894-95 (noting that opponents of assisted suicide believe that "death irreversibly alienates autonomy and cannot be condoned by appeal to autonomy").

36 See Leslie L. Mangini, Note, To Help or Not to Help: Assisted Suicide and its Moral, Ethical, and Legal Ramifications, 18 SETON HALL LEGIS. J. 728, 733 (1994).

37 Id. at 732.

38 Prohibitions against suicide and attempted suicide probably disappeared because "there is no form of criminal punishment that is acceptable for a completed suicide and . . criminal punishment is singularly inefficacious to deter attempts to commit suicide." MODEL PENAL CoDE $\S 201.5 \mathrm{cmt} .2$ (Proposed Official Draft 1962).

39 See, e.g., OR. ReV. STAT. $\$ 163.117$ (1993); see also Model PENAL CODE $\$ 201.5 \mathrm{cmt} .1$ (Tentative Draft No. 9, 1959) (concluding that assisted suicide should be prohibited); $c f$. Antonius $\mathbf{P}$. Tsarouhas, The Case Against Legal Assisted Suicide, 20 OHIO N.U. L. REV. 793, 795-96 (1993).

40 See, e.g., MOdel PEnal CODE $\$ 210.5 \mathrm{cmt}$. 5 (Proposed Official Draft 1962); $c f$. Compassion in Dying v. Washington, 79 F.3d 790, 817 (9th Cir. 1996) (acknowledging the State of Washington's unqualified interest in preserving life).

41 Model Penal Code $\$ 210.5 \mathrm{cmt} .5$ (Proposed Official Draft 1962).

42 See Mangini, supra note 36, at 731-32; see also infra text accompanying notes 193-97.

43. Yale Kamisar, Are Laws Against Assisted Suicide Unconstitutional?, HASTINGS CTR. REP., May-June 1993, at 32, 39; see also Herbert HENDIN, SUICIDE IN AMERICA 245 (2d ed. 1995) (arguing that "[i]ust as love-pact suicides rarely turn out to be affirmations of love, so the self- 
Critics perceive legalization of assisted suicide as the top of a slippery slope that would ultimately devalue human life. ${ }^{44}$

The slippery slope theory has been refuted in part by experience in the Netherlands, where euthanasia is accepted, though not legal. 45 Dutch authorities will not prosecute as long as three conditions are met:

First, the patient must take the initiative in requesting euthanasia and has to request euthanasia repeatedly, consciously, and freely. Second, the patient must be experiencing suffering that cannot be relieved by any means except death. Third, the physician must consult with another physician who agrees that euthanasia is acceptable in the particular case. ${ }^{46}$

In the Netherlands, it appears that when requests for euthanasia or assisted suicide have been fulfilled, those requests were explicit and persistent, and rarely made under pressure from others. ${ }^{47}$

One of the primary attacks against physician-assisted suicide relates to the doctor's perceived role as a "healer." 48 To become a physician, prospective doctors must take the Hippocratic Oath, which states, in relevant part, "I will give no deadly medicine to anyone if asked, nor suggest any such counsel." 49 Many believe that a physician dedicated to her role as a healer cannot reconcile assisting in the death of a patient.50 Yet doctors themselves generally support physician-assisted suicide in

sacrificial suicide may lend itself to becoming the instrument of tyranny of the healthy over the aged and infirm"); Nancy J. Osgood, Assisted Suicide and Older People-A Deadly Combination: Ethical Problems in Permitting Assisted Suicide, 10 IssUES L. \& MED. 415, 418 (1995) (arguing that sanctioning assisted suicide among the elderly devalues old age). But see generally GEORGE J. ANNAS, The Insane Root Takes Reason Prisoner: The Supreme Court and the Right to Die, in STANDARD OF CARE: THE LAW OF AMERICAN BIOETHICS 85, 92 (1993) (adapted from George J. Annas, The Long Dying of Nancy Cruzan, 19 LAW MED. \& HeALTH CARE 52 (1991) (noting that the "problem with the 'right to life' position is that it is exclusively a slippery-slope argument that ignores the current rights of real people in favor of the speculative harms that may be visited on future people").

44 See, e.g., Leon R. Kass, Is There a Right to Die?, HASTINGS CTR. REP., Jan.-Feb. 1993, at 34, 37-38; see also Compassion in Dying v. Washington, 79 F.3d 816, 830 (9th Cir. 1996) (noting that critics of the practice believe recognizing physician-assisted suicide will eventually lead to "court-sanctioned killing" of people deemed to pose an "unjustifiable burden on society").

45 See HENDin, supra note 43, at 250-77; Emanuel, supra note 28, at 1896; see also van der Maas et al., supra note 12, at 673 (finding that "physicians who had practiced euthanasia mentioned that they would be most reluctant to do so again" and that they would only do so "in the face of unbearable suffering and with no alternatives").

46 Emanuel, supra note 28, at 1896.

47 See van der Maas et al., supra note 12, at 672 . Interviews with physicians who had practiced euthanasia showed that in $96 \%$ of the cases, their patients had explicitly and persistently requested assistance. See id. In $94 \%$, the patients had made the request repeatedly. See id. In addition, $99 \%$ of physicians reported that they felt sure the requests had not been made under pressure from others. See id.

48 See Emanuel, supra note 28, at 1891-92.

49 Hippocrates, HipPOCRATIC Writings xiii (Francis Adams trans., Encyclopedia Britannica, Inc. 1952).

50 The American Medical Association (AMA) refuses to support physician-assisted suicide or active voluntary euthanasia, on the grounds that they are "contrary to the prohibition against using the tools of medicine to cause a patient's death." Decisions, supra note 2, at 2233. Some, however, envision a substantially broader role for doctors near the end of their patients' lives. See, e.g., Timothy E. Quill, A Midwife Through the DYING PRocess 1-5 (1996).

When medicine's purpose is defined solely in terms of curing and prolonging life, there 
some cases. ${ }^{51}$ Dr. Timothy Quill, for example, has used specific "sympathetic" cases to argue that a doctor's responsibility to relieve suffering encompasses prescribing a lethal dose of medication if necessary. 52 However, some commentators question the motives of those proposing legalization of assisted suicide. ${ }^{53}$

Critics argue that our society has moved toward accepting physician-assisted suicide primarily because it has failed to respond adequately to the needs of the elderly, terminally ill population. ${ }^{54}$ They contend that given universal health coverage, and better, more accessible hospice care, for example, people would choose to live. 55 . In this view, assisted suicide is a "quick-fix" that establishes a dangerous precedent. 56

is no clear direction when a patient is dying. Yet, healing has more to do with caring for the person who is ill than with simply extending biological life. . . Medicine's purpose should include helping persons become more whole and alleviating their Id. at 1 . suffering, as well as treating their diseases. . . Such is the role of a medical healer.

The AMA does, however, approve of the "double effect" standard. See Decisions, supra note 2 , at 2229,2233 . If a physician prescribes medication primarily to relieve a patient's pain and suffering, then she is performing a proper medical function although she knows the patient will die because of her actions. See id.; see also Compassion in Dying v. Washington, 79 F.3d 790, 828 n.102 (9th Cir. 1996).

Controversy surrounds this principle. George Annas argues that laws legalizing physicianassisted suicide are unnecessary, because physicians can currently prescribe lethal medications as long as they have "a legitimate medical use to terminally ill patients." George J. Annas, Death by Prescription: The Oregon Initiative, 331 NEw ENG. J. MED. 1240, 1242 (1994). In response, Dr. Quill has urged that the process become more open. See Timothy E. Quill, The Oregon Death with Dignity Act, 332 NEW ENG. J. MED. 1174, 1175 (1995). He notes that the double effect would exonerate physicians who knew their patients wanted to die, as long as the physicians intended that the prescribed medication be used to ease pain, not to cause death. See id. "Such laws and ethical distinctions reinforce pseudoconversations that are dangerous for patients and doctors, involving deception and unclear thinking at a time when honesty and openness are essential." Id.

51 A recent survey found that $66 \%$ of responding Oregon-based physicians felt physicianassisted suicide would be ethical in some cases. See Melinda A. Lee et al., Legalizing Assisted Suicide-Views of Physicians in Oregon, 334 NEw ENG. J. MED. 310, 311 (1996). A separate study of physicians in Michigan found that fewer than $20 \%$ favored a complete ban on assisted suicide. See Jerald G. Bachman et al., Attitudes of Michigan Physicians and the Public Toward Legalizing Physician-Assisted Suicide and Voluntary Euthanasia, 334 NEW ENG. J. MED. 303, 305 (1996).

52 See Timothy E. Quill, Death and Dignity: A Case of Individualized Decision Making, 324 NEW ENG. J. MED. 691 (1991). But see Annas, supra note 50, at 1243 (arguing that "'ideal' cases, like that described by Quill, are an insufficient basis for changing public policy in a country where medicine continues to be practiced in the context of bias and social inequality"). Dr. Quill has fought to overturn laws prohibiting physician-assisted suicide on constitutional grounds. See, e.g., Quill v. Vacco, 80 F.3d 716, 721 (2d Cir. 1996); see also discussion infra Part III.C.

53 See, e.g., Kass, supra note 44, at 37 (categorizing supporters of the "right to die" as "[c]hildren looking at parents who are not dying fast enough, hospital administrators and health economists concerned about cost-cutting and waste, [and] doctors disgusted with caring for incurables").

54 See, e.g., Emanuel, supra note 28, at 1895. These concerns stem in part from statistics demonstrating that the suicide rate in the United States rises with age. See HENDIN, supra note 43, at 81. "Persons over the age of 50, while making up 26 percent of the total United States population, account for approximately 39 percent of the total deaths by suicide each year." Id.

55 Cf. William G. Bartholome, Physician-Assisted Suicide, Hospice, and Rituals of Withdrawal, 24 J.L. MED. \& ETHICS 233, 233-34 (1996) (arguing for increased use of hospice care instead of suicide or assisted suicide).

56 However, the contention that in a world with ideal treatment options most suffering people would choose to live, does not lead invariably to the rejection of physician-assisted suicide. Presumably such a world would include some who would choose to die even after considering all of their options. Cf. QuILL, supra note 50, at 4 ("The notion that all requests to physicians for assisted 


\section{DO LAWS PROHIBITING ASSISTED SUICIDE IN ALL CIRCUMSTANCES VIOLATE THE U.S. CONSTITUTION?}

\section{A. PLANNED PARENTHOOD OF SOUTHEASTERN PENNSYLVANIA V. CASEY 57}

Reasonable grounds exist on which a court could find that the right of privacy extends to physician-assisted suicide.58 In Casey, the U.S. Supreme Court acknowledged a constitutional right of privacy, stating that matters

involving the most intimate and personal choices a person may make in a lifetime, choices central to personal dignity and autonomy, are central to the liberty protected by the Fourteenth Amendment. At the heart of liberty is the right to define one's own concept of existence, of meaning, of the universe, and of the mystery of human life. Beliefs about these matters could not define the attributes of personhood were they formed under compulsion of the state. 59

Few would dispute that death ranks among the most mysterious concepts that human beings confront. Terminally ill patients confront death while most others in society brush it aside. Similarly, pregnant women, by virtue of their condition, are uniquely situated to determine whether to terminate their pregnancies. ${ }^{60}$ Both terminally ill patients and pregnant women must evaluate their beliefs about existence and the mystery of human life, before acting. A broad reading of Casey suggests that a terminally ill patient's intimate choice to receive a lethal dose of medication should be protected by the Fourteenth Amendment. 61

One must note, of course, that although Casey reaffirmed the "essential holding" of Roe v. Wade, 62 it also substantially narrowed that decision.63 Under Casey, only those state limitations that pose an "undue burden" on a protected interest will be found unconstitutional. ${ }^{64}$ An unduly burdensome limitation "has the purpose or effect of placing a substantial obstacle in the path of a woman seeking an abortion."65 Still, it remains unclear how courts should apply the "undue burden"

death stem from undertreated pain, unrecognized depression, or some kind of character flaw is an illusion."). But $c f$. Emanuel, supra note 28, at 1895 (arguing that even though adequate comfort would not prevent great pain and suffering in some cases, "this does not mean [euthanasia] should be legalized under the guise of promoting the well-being of patients in general"). By prohibiting assisted suicide in all cases, society might "protect" those who would ideally prefer life, and work to improve end-of-life treatment options. However, this would reject the decisions of persons who would choose death regardless of their options, denying them the autonomy they would have enjoyed in the more "perfect" world.

57505 U.S. 833 (1992).

58 See Compassion in Dying v. Washington, 79 F.3d 790, 813-14 (9th Cir. 1996) (noting the similarities between a decision to have an abortion and a decision about how and when to die); Kathryn L. Tucker \& David J. Burman, Physician Aid in Dying: A Humane Option, a Constitutionally Protected Choice, 18 SEATTLE U. L. REV. 495, 500 (1995) (arguing that no sound basis exists for excluding physician-assisted suicide from the scope of protection defined by Casey).

59 Casey, 505 U.S. at 851.

60 See id. at 850-52.

61 See, e.g., Tucker \& Burman, supra note 58, at 500 .

62 See Casey, 505 U.S. at 845-46, aff'g Roe v. Wade, 410 U.S. 113 (1973).

63 See id. at 877-79.

64 See id. at $877-78$.

$65 \mathrm{Id}$. at 877. 
standard outside of the abortion context.66 Yet, assuming the existence of a liberty interest in choosing physician-assisted suicide, one could hardly argue that a law banning assisted suicide in all circumstances does not constitute an undue burden on its exercise. ${ }^{67}$

The argument in favor of a constitutionally protected liberty interest in physician-assisted suicide suffers because the purported right falls outside boundaries of the privacy right delineated by case law. ${ }^{68}$ The Court suggested that it would hesitate to broaden the scope of the privacy interest beyond matters involving "marriage, procreation, contraception, family relationships, child rearing, and education." 69 The abortion cases and related decisions "are not intended to lead automatically to the recognition of other fundamental rights on different subjects."70 Recent decisions such as Casey demonstrate the U.S. Supreme Court's reluctance to expand the right of privacy beyond its current scope.

\section{B. CRUZAN V. DIRECTOR, MISSOURI DEPARTMENT OF HEALTH 71}

Although the right of privacy may not include assisted suicide, a second line of cases offers a more realistic possibility for its protection. In Cruzan v. Director, Missouri Department of Health, the U.S. Supreme Court considered whether the parents of a woman who suffered an accident and had lost all cognitive abilities could withdraw life-sustaining treatment. ${ }^{72}$ The Missouri Supreme Court had ruled that Nancy Cruzan's parents could not order the removal of tubes providing her with food and hydration without clear and convincing evidence that she would have wanted to die in such a situation. ${ }^{73}$

On appeal, the U.S. Supreme Court upheld the Missouri standard. 74 Although at first glance this result might have discouraged proponents of a constitutional right to die, the decision eventually had the opposite effect. ${ }^{75}$ Chief Justice Rehnquist, writing for the Court, noted that the "principle that a competent person has a constitutionally protected liberty interest in refusing unwanted medical treatment

66 See Alan Brownstein, How Rights Are Infringed: The Role of Undue Burden Analysis in Constitutional Doctrine, 45 HASTINGS L.J. 867, 954 (1994) ("Inconsistencies and uncertainty in the application of the undue burden standard are unavoidable because there is no common foundation underlying the various rights that the Constitution protects.").

67 See Compassion in Dying v. Washington, 79 F.3d 790, 832, 834-35 (9th Cir. 1996) (describing the effect of Washington's prohibition of assisted suicide on the liberty interest of terminally ill people in choosing the time and manner of their deaths).

68 See Casey, 505 U.S. at 851.

69 Id. In Quill v. Koppell, the District Court for the Southern District of New York rejected the petitioners' claims that New York's prohibition of assisted suicide was contrary to the holdings of Roe and Casey. Quill v. Koppell, 870 F. Supp. 78, 83 (S.D.N.Y. 1994), rev'd sub nom. Quill v. Vacco, 80 F.3d 716 (2d Cir. 1996). The court stated that the plaintiffs' "reading of these cases is too broad." Quill, 870 F. Supp. at 83. But see Eisenstadt v. Baird, 405 U.S. 438, 453 (1972) (noting that if "the right of privacy means anything, it is the right of the individual . . to be free from unwarranted governmental intrusion into matters . . fundamentally affecting a person").

70 Quill, 870 F. Supp. at 83.

71497 U.S. 261 (1990).

72 See id. at 265.

73 See Cruzan v. Harmon, 760 S.W.2d 408, 425 (Mo. 1988).

74 See Cruzan, 497 U.S. at 280.

75 See Kass, supra note 44 , at 40. 
may be inferred from our prior decisions."76 Perhaps, then, a "constitutional right to die with assistance may be inferred from the Supreme Court's recognition of a constitutional right to refuse medical treatment, just as recognition of that right was inferred from prior Court holdings."77

A difficult yet critical question is whether the Court's assumption in Cruzan that the U.S. Constitution "would grant a competent person a constitutionally protected right to refuse lifesaving hydration and nutrition," 78 includes taking active steps to commit suicide. Many have argued that there is no significant difference between a competent person exercising the right to refuse treatment, knowing that such inaction will result in death, and a physician supplying a competent person with a lethal dose of medication. ${ }^{79}$ In both cases, a competent adult makes a decision that eventually will lead to death. Yet a physician's assistance in achieving that death may pose too far of a reach for the U.S. Supreme Court.

The Court would likely distinguish between active and passive steps, and hold that physician-assisted suicide is not protected. Courts and legislatures do not generally consider withdrawal of life-sustaining treatment suicide. ${ }^{80} \mathrm{In}$ fact, the right to withdraw life-sustaining treatment and hydration developed from a historic right to refuse treatment of any kind.81 Because obtaining a prescription for lethal medication from a doctor is not a refusal of treatment, the Court would likely remove the case for physician-assisted suicide from the reach of Cruzan. The Court would likely distinguish the act of ending life from an omission which has the same effect. ${ }^{82}$

Justice Scalia has criticized the active-passive distinction. "It would not make much sense to say that one may not kill oneself by walking into the sea, but may sit on the beach until submerged by the incoming tide . . ."83 Some commentators have agreed that no logical distinction exists between withdrawal of hydration and

76 Cruzan, 497 U.S. at 278.

77 Bjorck, supra note 9, at 390.

78 Cruzan, 497 U.S. at 279.

79 See, e.g., Tucker \& Burman, supra note 58, at 502-04 (contending that the liberty interest in refusing unwanted medical treatment cannot be distinguished from choosing to hasten inevitable death with active medical assistance); see also Quill v. Vacco, 80 F.3d 716, 727 (2d Cir. 1996) (finding one category of persons encompassing all those "in the final stages of fatal illness [who] wish to hasten their deaths"); Compassion in Dying v. Washington, 49 F.3d 586, 595 (9th Cir. 1995) (Wright, J., dissenting) (stating that a "Constitutional distinction cannot be drawn between refusing life-sustaining medical treatment and accepting physician assistance in hastening death"). But see U.S. Supreme Court Petitioner's Brief at *7, Vacco v. Quill, 1996 WL 656345 (No. 95-1858) (arguing that the right to forgo treatment "derives from the common law right to bodily integrity and freedom from unwanted physical intrusions [whereas the] asserted 'right' to physician-assisted suicide is ... a right to demand outside assistance in the taking of one's own life").

80 See, e.g., In re Quinlan, 355 A.2d 647, 665 (N.J. 1976) (noting "a real distinction between the self-infliction of deadly harm and a self-determination against artificial life support . . in the face of irreversible, painful and certain imminent death").

81 See ANNAS, supra note 43, at 90.

82 See 2 Alan Meisel, The Right to Die 460 (2d ed. 1995).

83 Cruzan, 497 U.S. 261, 266 (1990) (Scalia, J., concurring). One may easily infer that Justice Scalia opposes a constitutionally protected right to assisted suicide from this concurring opinion. He questioned, are there "reasonable and humane limits that ought not to be exceeded in requiring an individual to preserve his own life? There obviously are, but they are not set forth in the Due Process Clause." Id. at 300. 
physician-assisted suicide. ${ }^{84}$ Based on its opinion in Cruzan, however, it appears likely that the Court will make such a distinction. ${ }^{85}$ First, the Court merely assumed, but did not hold, that competent persons have a constitutionally protected right to refuse lifesaving hydration and nutrition. ${ }^{86}$ If the Court either proceeds with the same assumption, or actually holds that such a right exists, then it would have to determine whether there is a constitutionally significant difference between physician-assisted suicide and forgoing life-sustaining treatment. The Court suggested its willingness to distinguish these categories when it implied that statutes prohibiting assisted suicide are constitutional.87 In support of the state's interest in preserving life, Chief Justice Rehnquist wrote that "the majority of States in this country have laws imposing criminal penalties on one who assists another to commit suicide. We do not think a State is required to remain neutral in the face of an informed and voluntary decision by a physically able adult to starve to death."88 This statement suggests that the Court would find no constitutional infirmity in a state's ban of assisted suicide, and must, therefore, signal the existence of a line between a patient's right to refuse unwanted treatment and that patient's request for a lethal prescription. ${ }^{89}$

\section{QUILL V. VACCO 90}

In Quill v. Vacco, the U.S. Court of Appeals for the Second Circuit considered the claim that New York's prohibition of assisted suicide violated both the Due Process Clause and the Equal Protection Clause of the U.S. Constitution.91 The court, reversing a brief district court opinion, ${ }^{92}$ held that with respect to competent, terminally ill persons who request drugs from physicians to hasten their deaths, the law violated the Equal Protection Clause. ${ }^{93}$

The court affirmed the district court's rejection of the plaintiffs' claim that the right to assisted suicide is a fundamental liberty under the substantive component of the Due Process Clause. ${ }^{94}$ The court concluded that such a right could not properly

\footnotetext{
84 See Kass, supra note 44, at 41; Tucker \& Burman, supra note 58, at 503-04; see also MEISEL, supra note 82, at 460 (arguing that “'forgoings' of life-sustaining treatment can be accomplished either by withholding or by withdrawing, and withdrawing-for instance, the turning off of a ventilator-is no less of an act than a self-inflicted shooting, poisoning, wrist slitting, hanging, or even overdose of prescribed medication").

85 But see Quill v. Vacco, 80 F.3d 716, 729 (2d Cir. 1996) (assuming that persons authorized by statute to withdraw life-sustaining treatment are similarly situated with terminally ill persons who wish to take a lethal dose of medication).

86 See Cruzan, 497 U.S. at 279. But see Quill v. Vacco, 80 F.3d 716, 737 (2d Cir. 1996) (Calabresi, J., concurring) (concluding that despite its use of the term, the U.S. Supreme Court "did not merely 'assume' that a liberty interest in refusing life-sustaining medical treatment existed").

87 See Edward J. Larson, Seeking Compassion in Dying: The Washington State Law Against Assisted Suicide, 18 SEATTLE U. L. REV. 509, 511-12 (1995).

88 Cruzan, 497 U.S. at 280.

89 See Larson, supra note 87, at 512.

9080 F.3d 716 (2d Cir. 1996).

91 See id. at 718. The Constitution states, in relevant part, that "[n]o state shall . . deprive any person of life, liberty, or property, without due process of law; nor deny to any person within its jurisdiction the equal protection of the laws." U.S. CONST, amend. XIV, §1.

92 See Quill v. Koppell, 870 F. Supp. 78 (S.D.N.Y. 1994).

93 See Quill, 80 F.3d at 727.

94 See id. at 723.
} 
be included within the right of privacy. 95 The abortion cases, "and other related decisions on procreation and child rearing, are not intended to lead automatically to the recognition of other fundamental rights on different subjects."96 The court assumed that without support from these cases, the purported right would only be deemed "fundamental" if it were "deeply rooted in this nation's history and tradition" "97 or "so 'implicit in the concept of ordered liberty' that 'neither liberty nor justice would exist if [it] were sacrificed."'98 Because the plaintiffs produced insufficient evidence on either count, the court concluded that the case did not involve a fundamental right, 99 and therefore found no Due Process Clause violation. 100

The Quill court instead focused on the equal protection challenge to the law banning assisted suicide. The Equal Protection Clause of the Fourteenth Amendment requires that states "treat in a similar manner all individuals who are similarly situated." 101 The plaintiffs based their argument on the fact that a competent person has the right to withdraw life-sustaining treatment. ${ }^{102}$ They claimed that terminally

95 See id. at 724 (citing Bowers v. Hardwick, 478 U.S. 186, 192 (1986)).

96 Quill, 870 F. Supp. at 83.

97 Quill, 80 F.3d at 723 (quoting Moore v. City of East Cleveland, 431 U.S. 494, 503 (1977)).

98 Id. (quoting Palko v. Connecticut, 302 U.S. 319, 325-26 (1937)).

99 See id. at 724 . Contrary to the court's suggestion, history does not conclusively scorn suicide. For example, in 1789, David Hume wrote:

That suicide may often be consistent with interest and with our duty to ourselves, no one can question, who allows that age, sickness, or misfortune may render life a burden, and make it worse even than annihilation. I believe that no man ever threw away life while it was worth keeping.

David Hume, An Essay on Suicide, in David Hume: Selected Essays 315, 323 (Stephen Copley \& Andrew Edgar eds., 1993).

100 See Quill, 80 F.3d at 724-25. However, because the court employed oversimplified analysis, we cannot learn much from the due process discussion in Quill. First; the court incorrectly assumed that only a state's interference with a fundamental right may lead to a violation of the Due Process Clause. Cf. Compassion in Dying v. Washington, 79 F.3d 790, 803 (9th Cir. 1996) (noting that the Supreme Court's "evolving doctrinal approach" has led it to speak of "substantive due process interests" rather than "fundamental due process rights" in recent years). In both Casey and Cruzan, for example, the Court balanced nonfundamental liberty interests against legitimate state interests. See Planned Parenthood of Southeastern Pennsylvania v. Casey, 505 U.S. 833, 837 (1992); Cruzan v. Director, Missouri Dep't of Health, 497 U.S. 261, 278-79 (1990). In Casey, the joint opinion used a test whereby an "undue burden exists, and therefore a provision of law is invalid, if its purpose or effect is to place substantial obstacles in the path of a woman seeking an abortion before the fetus attains viability." Casey, 505 U.S. at 837.

The Court also overemphasized the importance of historical sanction in judging whether a right is fundamental. In Casey, the Court noted that making historical approval a prerequisite to constitutional protection would be

inconsistent with our law .... Marriage is mentioned nowhere in the Bill of Rights and interracial marriage was illegal in most States in the 19th century, but the Court was no doubt correct in finding it to be an aspect of liberty protected by the substantive component of the Due Process Clause.

Casey, 505 U.S. at 847-48 (citing Loving v. Virginia, 388 U.S. 1, 12 (1967)).

101 Quill, 80 F.3d at 725; see U.S. ConsT. amend. XIV, § 1. The court concluded that people who could refuse lifesaving treatment and people who wished a physician's aid in suicide were similarly situated. See Quill, 80 F.3d at 729. These two groups together constituted "competent persons who are in the final stages of fatal illness and wish to hasten their deaths." Id. at 727.

102 See N.Y. Pub. Health LaW $\$ § 2960-79$ (McKinney 1993); Quill v. Koppell, 870 F. Supp. 78, 84 (S.D.N.Y. 1994); see also Cruzan, 497 U.S. at 278. Life-sustaining treatment includes "mechanical ventilation, renal dialysis, chemotherapy, antibiotics, and artificial nutrition and hydration." Decisions, supra note 2, at 2229. 
ill patients seeking physicians' aid in hastening death were similarly situated, and that the state had no justification for treating them differently. 103

States that treat similarly situated people differently subject themselves to various levels of judicial scrutiny. 104 The court determined that rational basis review was the appropriate standard in evaluating laws prohibiting assisted suicide. ${ }^{105}$ Like other social welfare legislation, this law would pass judicial scrutiny if the classification drawn rationally furthered a legitimate state purpose. 106

The court concluded that the distinction failed to pass even the low level of scrutiny imposed by rational basis review.107 The court held that "to the extent that the statutes in question prohibit persons in the final stages of terminal illness from having assistance in ending their lives by the use of self-administered, prescribed drugs, the statutes lack any rational basis and are violative of the Equal Protection Clause."108

Certain aspects of Quill are problematic. First, the court's basis for its conclusion that those who may remove life-sustaining treatment are similarly situated to those who wish to obtain a lethal prescription was mistaken. The district court ruled that "[i]n any event, it is hardly unreasonable or irrational for the State to recognize a difference between allowing nature to take its course, even in the most severe situations, and intentionally using an artificial death-producing device."109 The Second Circuit criticized this view, reasoning that both situations involve active steps to hasten death. 110

By ordering the discontinuance of these artificial life-sustaining processes or refusing to accept them in the first place, a patient hastens his death by means that are not natural in any sense. It certainly cannot be said that the death that immediately ensues is the natural result of the progression of the disease or condition from which the patient suffers. ${ }^{111}$

One could, however, legitimately view the withdrawal of life-sustaining treatment as "letting nature take its course." If no technology existed to keep the patient alive, then the disease already would have caused that person's death. Adding a respirator can be seen as an artificial delay in the natural course of dying. ${ }^{112}$

Even if the physical act of "pulling the plug" is unnatural in some respects, it differs significantly from obtaining a doctor's prescription for a lethal dose of medication. The U.S. Constitution protects the right to refuse treatment, including cases where the refusal will result in death, but no corresponding right exists to

\footnotetext{
103 See Quill, 870 F. Supp. at 84.

104 See Quill, 80 F.3d at 725-27.

105 See id. at 726.

106 See id. (citing Hooper v. Bernalillo County Assessor, 472 U.S. 612, 618 (1985)).

107 See id. at 727.

$108 \mathrm{Id}$.

109 Quill v. Koppell, 870 F. Supp. 78, 84 (S.D.N.Y. 1994).

110 See Quill, 80 F.3d at 729.

$111 \mathrm{Id}$.

112 The AMA apparently supports this interpretation. See Decisions, supra note 2, at 2229. It defines treatment as "life-sustaining" when it "serves to prolong life without reversing the underlying medical condition." Id.
} 
obtain "treatment" such as a lethal dose of medication.113 "Americans have never been obligated to accept any or all manner of medical treatment available to prolong life; the essence of the legal right at stake is the right to be free from unwanted bodily invasions." 114

The withdrawal of life-sustaining treatment should not, therefore, be classified as suicide. Rather, death results from the disease which prompted medical care initially. Physician-assisted suicide causes a person who would otherwise have lived without any medical attention to die. It is a form of suicide. As physician-assisted suicide may properly be seen as suicide, and withdrawal of life-sustaining treatment may not, the court erred by finding them to be similarly situated.

\section{COMPASSION IN DYING V. WASHINGTON 115}

In Compassion in Dying v. Washington, the plaintiffs-four physicians, three terminally ill patients and a non-profit organization-challenged the constitutionality of Washington's statute prohibiting assisted suicide.116 The law provides that a "person is guilty of promoting a suicide when he knowingly causes or aids another person to attempt suicide." 117 The district court saw Casey as "almost prescriptive" in finding a liberty interest in physician-assisted suicide. 118 The court concluded that "the suffering of a terminally ill person cannot be deemed any less intimate or personal, or any less deserving of protection from unwarranted governmental interference, than that of a pregnant woman."119 As such, the choice of whether to commit physician-assisted suicide resides with those liberties protected by the U.S. Constitution. ${ }^{120}$ Because Washington unequivocally prohibits assisted suicide, the court declared that the law unduly burdened the exercise of competent, terminally ill persons' rights to exercise a protected liberty interest. 121

On appeal, a three-judge panel of the Ninth Circuit rejected this reasoning:

To take three sentences out of an opinion over thirty pages in length dealing with the highly charged subject of abortion and to find these sentences "almost prescriptive" in ruling on a statute proscribing the promotion of suicide is to make an enormous leap, to do violence to the context, and to ignore the differences between the regulation of reproduction and the prevention of the promotion of killing a patient at

113 See George J. Annas, The Promised End-Constitutional Aspects of Physician-Assisted Suicide, 335 NEW ENG. J. MED. 683, 684 (1996).

114 Id.

11579 F.3d 790 (9th Cir. 1996).

116 See $i d$. at 794.

117 WASH. REV. CODE ANN. $\$ 9$ A.36.060 (West 1991). Violating the statute constitutes a felony punishable by up to five years in prison, and a $\$ 10,000$ fine. See id. $\$ \$ 9 A .36 .060(2)$, $.20 .020(1)(c)$.

The plaintiffs did not object to the portion of the statute that makes it unlawful for a person to "cause" someone to commit suicide. See Compassion in Dying, 79 F.3d at 797. They challenged the "or aids" portion of the statute both on its face and as applied to mentally competent, terminally ill adults who wish to hasten their deaths with the help of medication prescribed by their doctors. See id.

118 See Compassion in Dying v. Washington, 850 F. Supp. 1454, 1459-60 (W.D. Wash. 1994).

$119 \mathrm{Id}$. at 1460 .

120 See id.

121 See id. at 1465. 
his or her request. 122

The court distinguished Casey, 123 and found no constitutional violations in Washington's prohibition of assisted suicide.124 Citing its "extraordinary importance," the Ninth Circuit decided to rehear the case en banc. 125

The court first considered whether a liberty interest exists in "choosing the time and manner of one's death-a question sometimes phrased in common parlance as: Is there a right to die?"'126 According to the court, the range of liberties guaranteed by the Due Process Clause reside on a "'rational continuum which, broadly speaking, includes a freedom from all substantial arbitrary impositions and purposeless restraints."'127

The court examined historical and current perspectives, noting that at the time of the Fourteenth Amendment's adoption, only nine out of thirty-seven states had statutory prohibitions of assisted suicide. 128 Today, most Americans favor legalized physician-assisted suicide.129 However, the court relied primarily on case law, especially Casey and Cruzan, to find a liberty interest in choosing the time and manner of death. 130

Extrapolating from language in Casey, the court noted that like "the decision of whether or not to have an abortion, the decision how and when to die is one of 'the most intimate and personal choices a person may make in a lifetime,' a choice 'central to personal dignity and autonomy."'।31 Like abortion, choosing to "die with dignity" implicates a vital liberty interest. 132

In Cruzan, Chief Justice Rehnquist recognized that "[t]he principle that a competent person has a constitutionally protected liberty interest in refusing unwanted medical treatment may be inferred from our prior decisions." 133 Refusing unwanted care includes the withdrawal of life-sustaining treatment, a course of action that necessarily induces the patient's death. 134 The Ninth Circuit concluded that Cruzan, by recognizing a liberty interest that includes refusal of life-sustaining treatment, must also recognize a liberty interest in hastening one's own death. ${ }^{135}$

122 Compassion in Dying v. Washington, 49 F.3d 586, 590 (9th Cir. 1995).

123 See id. at 590-91.

124 See id. at 594.

125 See Compassion in Dying v. Washington, 62 F.3d 299 (9th Cir. 1995) (granting a rehearing en banc); see also Compassion in Dying v. Washington, 79 F.3d 790, 798 (9th Cir. 1996) (commenting that the rehearing had been granted because of the case's "extraordinary importance").

$126 \mathrm{Id}$. at 798-99. The liberty interest is not in "committing suicide," but in "controlling the time and manner of one's death," because the interest encompasses a broader range of activities than suicide, including the act of refusing or terminating unwanted medical treatment. Id. at 802 .

127 Id. at 800 (quoting Poe v. Ullman, 367 U.S. 497, 543 (1961) (Harlan, J., dissenting)). The court did not consider whether the interests involved rose to the level of "fundamental rights." See id. at 803-04.

128 See $i d$. at 809 . The court noted generally that "while historical analysis plays a useful role in any attempt to determine whether a claimed right or liberty interest exists, earlier legislative or judicial recognition of the right or interest is not a sine qua non." Id. at 805 .

129 See id. at 810.

130 See id. at 813; see also Euthanasia Favored in Poll, N.Y. TIMES, Nov. 4, 1991, at A16.

$131 \mathrm{Id}$. at 813-14 (quoting Casey, 505 U.S. at 851).

132 See id. at 814.

133 Cruzan, 497 U.S. at 278.

134 See Compassion in Dying, 79 F.3d at 815-16.

135 See id. at 816. 
After finding a liberty interest in controlling the time and manner of one's death, the court considered whether the state's prohibition of assisted suicide impermissibly burdened that interest with respect to competent, terminally ill adults wishing to hasten their deaths. ${ }^{136}$ The court rejected the dissent's contention that state actions are subject to a rational basis test when the liberty interest involved does not rise to the level of a fundamental right. ${ }^{137}$ Applying a balancing test, the court stated that as long as the "liberty interest is an important one, the state must shoulder the burden of justifying any significant limitations it seeks to impose."138

The court examined each of the state's legitimate interests and concluded that none outweighed the liberty interest previously identified.139 For example, although the state has an unqualified interest in preserving life, including the lives of terminally ill adults, the strength of that interest fluctuates from case to case. 140 The state's interest decreases when patients cannot pursue happiness or liberty, and no longer wish to live.141 "Thus, while the state may still seek to prolong the lives of terminally ill ... patients or, more likely, to enact regulations that will safeguard the manner in which decisions to hasten death are made, the strength of the state's interest is substantially reduced in such circumstances." 142

Like the preservation of life, the strength of the state's interest in preventing suicide diminishes in the case of competent, terminally ill adults who wish to die..$^{143}$ Unlike others who may wish to commit suicide, people with terminal illnesses cannot be cured, and frequently cannot find any enjoyment in life. 144 "Not only is the state's interest in preventing such individuals from hastening their deaths of comparatively little weight, but its insistence on frustrating their wishes seems cruel indeed."145

The state also has an interest in protecting infirm, elderly persons from undue pressure to end their lives from callous, financially burdened, or self-interested relatives, or others with influence over them. ${ }^{146}$ The court noted, however, that knowledge of a person's impending death will ordinarily restrain the temptation to exert undue pressure. ${ }^{147}$ The court acknowledged that some terminally ill adults

136 See id.

137 See id. at 804.

$138 \mathrm{Id}$. According to the court, the strength of the liberty interest fluctuates depending on certain factors, especially the individual's physical condition. See id. at 834. "When a mentally competent adult is terminally ill and wishes, free of any coercion, to hasten his death because his remaining days are an unmitigated torture, that person's liberty interest is at its height." Id.

139 See id. at 836-37.

140 See id. at 817.

141 See id. at 820 .

142 Id.

143 See id.

144 See id. at $820-21$.

$145 \mathrm{Id}$. at 821 . The court noted that the state's interest in preventing suicide may not even be implicated in this case. See id. at 824 . Notwithstanding the use of the term "physician-assisted suicide," the court found no significant difference between the prescription of a lethal dose of medication and a patient's decision to terminate life support or refuse food and hydration (actions which the state does not consider to be "suicide"). See id.

146 See id. at 826.

147 See id. 
might request the lethal dose of medication to protect their families from the expense of prolonged medical treatment. ${ }^{148}$ However, although

state regulations can help ensure that patients do not make rash, uninformed, or ill considered decisions, we are reluctant to say that, in a society in which the costs of protracted health care can be so exorbitant, it is improper for competent, terminally ill adults to take the economic welfare of their families and loved ones into consideration. 149

The state has a legitimate interest in maintaining the integrity of the medical profession, an interest that prevents physicians from engaging in conduct at odds with their role as healers. 150 This should not prevent physicians from providing lethal medication, however. Instead, "it is the existence of a statute that criminalizes the provision of medical assistance to patients in need that could create conflicts with the doctors' professional obligations and make covert criminals out of honorable, dedicated, and compassionate individuals." 151 In addition, many physicians have discretely aided terminally ill patients to hasten death for decades, without compromising their ethical standards or the reputation of the medical profession. ${ }^{152}$

In applying the balancing test, the court considered not only the state's legitimate interests, but also the means by which they had been implemented.153 Without denying the importance of the state's purposes, the court decried the harshness of an outright prohibition of assisted suicide.154 The state could satisfy its interests more fairly by establishing "appropriate, reasonable, and properly drawn safeguards" to assure the competency of the person requesting lethal medication. ${ }^{155}$

Given that the "liberty interest in hastening death is at its strongest when the state's interest in protecting life and preventing suicide is at its weakest, and viceversa," the court concluded that the state could not constitutionally prohibit consenting, terminally ill adults from choosing physician-assisted suicide. ${ }^{156}$ The court held that "a liberty interest exists in the choice of how and when one dies, and that the provision of the Washington statute banning assisted suicide, as applied to competent, terminally ill adults who wish to hasten their deaths by obtaining medication prescribed by their doctors, violates the Due Process Clause." 157

If affirmed by the U.S. Supreme Court, the Ninth Circuit's opinion in Compassion in Dying would have vast implications. Within the Ninth Circuit, the decision would render all state laws unequivocally banning assisted suicide inapplicable to competent, terminally ill patients. In addition, the ruling would

148 See id.

149 Id.

150 See id. at 827.

151 Id. But see Decisions, supra note 2, at 2232 (condemning "the gradual distortion of the role of medicine into something that starkly contrasts with the current vision of a profession dedicated to healing and comforting").

152 See Compassion in Dying, 79 F.3d at 828; see also supra notes 50-51.

153 See Compassion in Dying, 79 F.3d at 832.

154 See id.

$155 \mathrm{Id}$. at 833 . The court noted some potential procedural safeguards, "without endorsing [their] constitutionality." Id. Examples included witnesses to ensure voluntariness, short waiting periods to prevent impulsive decisions and psychological evaluations to guarantee that the patient does not suffer from treatable depression. See id.

$156 \mathrm{Id}$. at $836-37$.

157 Id. at 838. 
reverse Lee v. Oregon, in which the District Court of Oregon ruled that an Oregon initiative which would have allowed physician-assisted suicide in certain circumstances violated the Equal Protection Clause. 158

\section{LEGALIZED ASSISTED SUICIDE}

\section{A. PhySICIAN-ASSISTED SUICIDE IN THE UNITED STATES}

Oregon voters were not the first to consider a variation of the Death with Dignity Act. Washington's ballot initiative was defeated by a margin of fifty-four to forty-six percent in 1991.159 The Washington act, similar in many respects to Oregon's Measure 16, would have allowed mentally "competent" patients with terminal conditions to request physician-assisted "aid in dying." 160 . Some commentators suggest that voters rejected the measure because it neither set forth sufficiently specific procedures for implementing the "aid in dying," nor did it adequately define the physician's role.161. However, the Act's scope apparently included both voluntary euthanasia and physician-assisted suicide. 162 Despite its vagueness, the initiative "quantified the level of public support for assistance in dying and also provided the impetus for similar legislation in California."163

\section{B. THE OREGON DEATH WITH DIGNITY ACT}

An adult who is capable, is a resident of Oregon, and has been determined by the attending physician and consulting physician to be suffering from a terminal disease, and who has voluntarily expressed his or her wish to die, may make a written request for medication for the purpose of ending his or her life in a humane and dignified manner in accordance with this act. 164

Measure 16 sets forth various requirements and safeguards for physician-assisted suicide. 165 "Terminal disease" is defined as "an incurable and irreversible disease that has been medically confirmed and will, within reasonable medical judgment,

158 See Lee v. Oregon, 891 F. Supp. 1429, 1437 (D. Or. 1995). Although the expected appeal of Lee was not at issue here, the court described the holding reached in that case as "highly irregular," and noted that Chief Judge Hogan, author of the Lee opinion, had "clearly erred." See Compassion in Dying, 79 F.3d at 838.

159 See Cheryl K. Smith, What About Legalized Assisted Suicide?, 8 IssUES L. \& MED. 503, 503 (1993).

160 See Jody B. Gabel, Release From Terminal Suffering?: The Impact of AIDS on Medically Assisted Suicide Legislation, 22 FLA. ST. U. L. REV. 369, 411 (1994) (citing the proposed amendment to WASH. REV. CODE $\$ 70.122 .060(1)$ (1991), reprinted in OFFICE OF THE SECRETARY OF the State of WAShington, Voters PAMPhLet, Initiative Measure 1/9, at 29).

161 See id. at 413.

162 See Annas, supra note 50, at 1240. "Euthanasia and assisted suicide differ in the degree of physician participation. Euthanasia entails a physician performing the immediate life-ending action ... . Assisted suicide occurs when a physician facilitates a patient's death by providing the necessary means and/or information to enable the patient to perform the life-ending act." Decisions, supra note 2, at 2229 .

163 Gabel, supra note 160 , at 413 .

164 Death with Dignity Act, OR. REV. STAT. ch. 127.805, $\$ 2.01$ (1995).

165 See id. chs. 127.800-.897. 
produce death within six (6) months."166 Requests for medication must be witnessed by two individuals who attest that the patient is "capable, acting voluntarily, and is not being coerced to sign the request." 167 The attending physician is required to determine whether the patient has a terminal disease, and has made a voluntary request for medication. 168 The physician must also inform the patient of alternatives to suicide, refer the patient to a consulting physician for a mandatory second opinion for confirmation of the original diagnosis and refuse to give the patient the lethal medication if it appears that he or she suffers from a psychological disorder or depression causing impaired judgment. 169 Clearly, the drafters of Measure 16 intended to shield doctors and patients from possible abuses of the system. ${ }^{170}$

However, in invalidating Measure 16, the U.S. District Court for the District of Oregon noted that its protections against abuses of the system were inadequate. ${ }^{171}$ In particular, the court took issue with the "imprecision and inadequacy of protections leading to the prescription of drugs."172 Although Measure 16 sets forth the conditions under which a person will receive the medication, it does not require the recipient to take the medication at any particular time or place, and does not demand supervision. ${ }^{173}$ This leaves the potential for people who physicians deem competent at the time they prescribe the medication to suffer undue influence at some later point. The "relationship between Measure 16's classification and the goal of permitting assisted suicide is too attenuated without some protection at the time of taking the fatal drug dosage."174

\section{WHETHER THE DisTRICT COURT CORRECTLY RULED THAT MEASURE 16 VIOLATES THE EQUAL PROTECTION CLAUSE OF THE FOURTEENTH AMENDMENT TO THE U.S. CONSTITUTION}

In Lee v. Oregon, Judge Hogan held that Measure 16 violates the Equal Protection Clause, because it denies the terminally ill the same protection against suicide afforded the remainder of Oregon's citizens. ${ }^{175}$. The court found no rational relation between Measure 16's denial of protection to depressed, terminally ill

166 Id. ch. $127.800, \S 1.01(12)$.

167 Id. ch. $127.810(1), \S 2.02(1)$.

168 See id. ch. $127.815, \S 3.01$.

169 See id. ch. 127.815, $\S 3.01(2)-(3) ; i d$. ch. $127.825, \S 3.03$. Critics of legalized assisted suicide argue that physicians would be unable to make accurate psychological evaluations. See HENDIN, supra note 43 , at 243 . This might be critical, assuming that, "like other suicidal individuals, patients who desire an early death during a terminal illness [usually suffer] from a treatable mental illness, most commonly a depressive condition." Id. at 242-43. According to Dr. Hendin, a "thorough psychiatric evaluation for the presence of a treatable disorder may literally make a life or death difference for patients who say they wish to die or to have a physician help them to do so." Id. at 243. These observations do not justify the continued prohibition of assisted suicide. They do, however, counsel in favor of supplementing existing safeguards with mandatory psychiatric evaluation.

170 Drafters of Measure 16 expected its enactment in part because its scope was more limited than failed initiatives in California and Washington. See Annas, supra note 50, at 1241.

171 See Lee v. Oregon, 891 F. Supp. 1429, 1437 (D. Or. 1995).

$172 \mathrm{Id}$.

173 See id.

$174 \mathrm{Id}$.

175 See id. at 1438. 
people from their suicidal impulses and the state's interests. 176 The reasoning behind the court's conclusion provides an opportunity to test its equal protection analysis.

Courts choose among levels of scrutiny when considering cases that implicate the Equal Protection. Clause. 177 . If the statute is based on a "suspect classification"178 such as race or national origin; or if it restricts a "fundamental" right such as the right to procreate or the right to vote, ${ }^{179}$ strict scrutiny is the applicable standard of review. A law passes strict scrutiny when it is necessary to further a compelling governmental interest. ${ }^{180}$

If the law fails to affect a suspect class of persons or restrict a fundamental right, then courts will generally apply a rational relation test, under which legislation is presumed valid if "a classification drawn by a statute is rationally related to a legitimate state interest."181 The court purported to use the rational relation test because the "terminally ill" is an ordinary (not "suspect") classification. ${ }^{182}$ A classification rationally furthers a state interest when there is some fit between the disparate treatment and the legislative purpose. 183 A classification cannot fail the rational relation test "so long as 'it is evident from all the considerations presented to the [lawmaker] . . . that the question is at least debatable."'184

Appropriate equal protection analysis therefore requires a judicial determination both of the legitimacy of a state's interest, and of the means the state chose to effectuate its goal. ${ }^{185}$ Oregon claimed the following interests in allowing physician-assisted suicide for the terminally ill:

(1) avoiding unnecessary pain and suffering; (2) preserving and enhancing the right of competent adults to make their own critical health care decisions; (3) avoiding tragic cases of attempted or successful suicides in a less humane and dignified manner; (4) protecting the terminally ill and their loved ones from financial hardships they wish to avoid; and (5) protecting the terminally ill and their loved ones from unwanted intrusions into their personal affairs by law enforcement officers and others. ${ }^{186}$

176 See id. at 1437.

177 See City of Cleburne v. Cleburne Living Ctr., Inc., 473 U.S. 432, 439-41 (1985) (discussing standards of scrutiny employed by courts to determine state legislation's validity under an equal protection challenge).

178 See City of Richmond v. J.A. Croson Co., 488 U.S. 469, 493-95 (1989) (holding that discrimination against any racial group merits strict scrutiny).

179 See Harper v. Virginia Bd. of Elections, 383 U.S. 663, 668, 670 (1966) (holding that poll taxes restrict the fundamental right to vote, and thus violate the equal protection clause).

180 See City of Cleburne, 473 U.S. at 440.

181 Lee, 891 F. Supp. at 1437; see Schweiker v. Wilson, 450 U.S. 221, 230 (1981) (stating that the Court has required legislation which classifies groups of people to be, at a minimum, rationally related to a legitimate governmental objective).

182 See Lee, 891 F. Supp. at 1431 n.2.

183 See id. at 1432.

184 Minnesota v. Clover Leaf Creamery Co., 449 U.S. 456, 464 (1981) (quoting United States v. Carolene Products Co., 304 U.S. 144, 153-54 (1938)).

185 It is irrelevant for the purposes of constitutional analysis that the public enacted Measure 16 by referendum, as opposed to traditional legislative process. See Citizens Against Rent Control v. City of Berkeley, 454 U.S. 290, 295 (1981).

186 Lee, 891 F. Supp. at 1434 . Measure 16 would limit the right to receive a lethal dose of medication to those with fewer than six months to live. See Death with Dignity Act, OR. REV. STAT. ch. $127.800, \S 1.01$; id. ch. $127.805, \S 2.01$. Some of the Measure's proponents would eventually 
The Oregon court made no finding that any of the state's interests were illegitimate. 187 Under rational basis review, the court next moved to the fit between the means employed by Measure 16 and the state's legitimate interests. ${ }^{188}$

The court employed faulty reasoning in reaching its conclusion that no rational relation existed between the classification drawn and the legitimate state interests. The court misinterpreted the means employed to further the end involved. Measure 16 intended to grant the right of physician-assisted suicide to competent, terminally ill people to further the goal of preventing suffering, among other things. 189 However, the court analyzed the classification in an entirely different light, considering Measure 16 together with Oregon's law prohibiting assisted suicide generally. ${ }^{190}$ The court then declared that the primary purpose of that statute was to protect the population against suicide.191 As such, Measure 16 served as an exception to Oregon's prohibition against assisted suicide, denying the terminally ill the same protection from suicide that the rest of the population enjoyed.192 From this perspective, it becomes somewhat easier to understand the court's conclusion that no rational relation existed in this case. Denying the terminally ill protection from their suicidal impulses may not relate closely to a state goal of preventing suffering, or enhancing the rights of competent adults to make critical health care decisions.

Underlying the court's decision is the notion that Oregon's prohibition of assisted suicide is based on interests in the "preservation of life and protection

extend the privilege to all consenting adults, a fact that did not escape the court's notice. See Lee, 891 F. Supp. at 1432 . Judge Hogan, while purporting to analyze the relevant constitutional issues in the context of the much smaller class defined in the statute, seemed concerned about a slippery slope:

While a diagnosis of terminal illness with less that [sic] six months to live may be a persuasive rational basis for some to choose suicide, there is little limit to the justifications which can be advanced for state-sanctioned suicide. Where in the Constitution do we find distinctions between the terminally ill with six months to live, the terminally ill with one year to live, paraplegics, the disabled, or any category of people who have their own reasons for not wanting to continue living?

Id. at 1432 n.3. Although such considerations may concern the court, potential future classifications should not have interfered with its equal protection analysis of the classification as drawn.

187 See id. at 1434-37 (noting that the act furthers asserted state interests, but holding equal protection violation based on "severely overinclusive class").

188 See id. at 1434.

189 See id. Consideration of Measure 16 as denying a right to a particular group is suspicious, because the law was obviously intended to grant an additional right to that class. Equal protection analysis based on the classification as obviously intended by the electorate (granting a right to competent, terminally ill people) shows more than a mere rational relation to the goal of preventing suffering. Fifty-two percent of Oregon voters believed in the strength of the connection. See Caplan, supra note 11 , at 3 .

190 See id. at 1433-34; see also OR. REV. STAT. $\$ 163.117$ (1995) (providing "aiding commission of suicide" as a defense to murder, but not to manslaughter or other crimes).

191 See Lee, 891 F. Supp. at 1434. Judge Hogan seems to premise his ruling on the idea that laws banning assisted suicide actually prevent people from committing suicide: "Measure 16 singles out terminally ill persons who want to commit suicide and excludes them from the protection of Oregon laws that apply to others." $J d$. at 1438 . However, approximately 15 states do not criminalize assisted suicide, seemingly with negligible impact. See MEISEL, supra note 82, at 478.

192 See Lee, 891 F. Supp. at 1438. In Compassion in Dying $v$. Washington, the Ninth Circuit rejected Judge Hogan's reasoning on this point: "The benefit we conclude the terminally ill are entitled to receive in this case-the right to physician-assisted suicide-is precisely what Judge Hogan determined to be a burden and thus unlawful. In short, Lee treats a burden as a benefit and a benefit as a burden. In doing so, Judge Hogan clearly erred." 79 F.3d 790, 838 (9th Cir. 1996). 
against suicide."193 Yet, as previously noted, laws against assisted suicide derive from English common law, ${ }^{194}$ which was largely based on religious ideology. 195 Christianity condemns suicide as self-murder, and a direct contradiction of the Sixth Commandment decree that "[t]hou shalt not kill."196 Clearly, state laws which criminalize assisted suicide are based on moral and religious beliefs, ${ }^{197}$ rather than concern that without such laws, incompetent or severely depressed persons may be more likely to kill themselves. Even if we assume, however, that underlying the prohibition of assisted suicide is protection of citizens from taking their lives, the district court's ruling appears faulty.

The court declared that "[i]t is 'rational' to conclude that competent terminally ill persons may not want protection from their suicidal impulses."198 Although Measure 16 tailored its classification to competent adults, the court found insufficient safeguards in the competency determination. ${ }^{199}$ Central to the court's ruling is its concern that Measure 16 would not prevent mentally incompetent, terminally ill patients from committing suicide. 200 The court stated that suicide is an improper alternative whenever patients suffer from treatable depression or mental illness. ${ }^{201}$

Because certain terminally ill patients may wish to commit suicide because of impaired judgment due to treatable depression, the court reasoned that the state failed to serve its interest in enhancing personal autonomy in health care decision making. ${ }^{202}$ The state had argued that because the right to assisted suicide applies only to "competent" adults, the danger of mentally disturbed terminally ill patients receiving the medication is reduced. ${ }^{203}$ Under Measure 16, the patient's request for the medication must be witnessed by at least two individuals who attest that "to the best of their knowledge and belief the patient is capable, acting voluntarily, and is

193 Lee, 891 F. Supp. at 1434.

194 See Mary M. Penrose, Assisted Suicide: A Tough Pill to Swallow, 20 PEPP. L. REV. 689, 701 (1993).

195 See id. at 696-700.

196 Exodus 20:13. "Although most interpreters agree that the Sixth Commandment apparently is not a direct mandate against suicide, the implication is that suicide is analogous to homicide, and therefore is similarly covered by the Sixth Commandment's mandate against killing." Penrose, supra note 194, at 696 n.41. Both Judaism and Islam parallel ideology of the Catholic Church, rejecting suicide as direct taking of human life. See Mangini, supra note 36, at 736-37.

197 See generally Penrose, supra note 194, at 696 (noting that the religious influence of the Catholic Church "is certain to pervade the assisted suicide debate in a similar manner" to that of the abortion debate). These laws stem from the idea that "[e]veryone has a moral duty to respect the sanctity of human life, that is, to refrain from any act that can reasonably be expected to cause another human being's death." BURTON M. LEISER, LIBERTY, JUSTICE, AND MORALS: CONTEMPORARY VALUE CONFLICTS 107 (2d ed. 1979) (discussing abortion laws).

198 Lee, 891 F. Supp. at 1434.

199 See id.

200 See id. at 1433.

201 See id. at 1434.

202 See id. at 1433.

203 See id. at 1434. The court's references to "incompetent" individuals parallel Measure 16's use of the word "incapable," meaning that when "in the opinion of the court or in the opinion of the patient's attending physician or consulting physician, a patient lacks the ability to make and communicate health care decisions to health care providers, including communication through persons familiar with the patient's manner of communicating if those persons are available." Death with Dignity Act, OR. REV. STAT. ch. $127.800, \S 1.01(6)$. 
not being coerced to sign the request."204 In addition, the first attending physician must make an "initial determination of whether a patient ... is capable." 205 After the determination is made, the first attending physician must refer the patient to a "consulting physician" for "medical confirmation of the diagnosis, and for a determination that the patient is capable."206

Either the attending or the consulting physician may, "if appropriate," refer the patient for counseling. ${ }^{207}$ Measure 16 makes clear that "[n]o medication to end a patient's life in a humane and dignified manner shall be prescribed until the person performing the counseling determines that the patient is not suffering from a psychiatric or psychological disorder, or depression causing impaired judgment."208

Despite these protections, the court reasoned that some mentally incompetent, terminally ill patients would "slip through the cracks" and receive the lethal medication because the "procedures designed to differentiate between the competent and incompetent are not sufficient."209 This occurs primarily because the physicians charged with making such judgments may not have sufficient training. ${ }^{210}$ The court noted that under "Measure 16 , a treating physician must determine when a person is beyond help and not merely suffering from treatable depression common in people with terminal illnesses."211

Basing a competency decision on whether a person is suffering from treatable depression "common in people with terminal illnesses" may be problematic. It seems reasonable to expect that persons diagnosed with a terminal disease will be depressed.212 It does not follow, however, that the state should prevent them from receiving the lethal dose of medication. It is less likely that a person completely at ease with his or her illness will take advantage of physician-assisted suicide. For this reason, the drafters of Measure 16 probably meant to include only the truly despondent and irrational, rather than persons with treatable depression, in the Act's definition of those for whom "depression caus[es] impaired judgment."213 Yet because of its perceived inadequacies, the court determined that the classification drawn ("terminally ill" patients) was overinclusive.214

The court may have correctly found Measure 16 overinclusive. It is possible to imagine that the attending and consulting physicians might prescribe lethal medication after mistakenly assessing the patient's competency. However, the court describes the class as defined by Measure 16 as "severely overinclusive." 215 Although some individuals within the classification should not receive the medication, the court fails to cite evidence that this subgroup composes more than

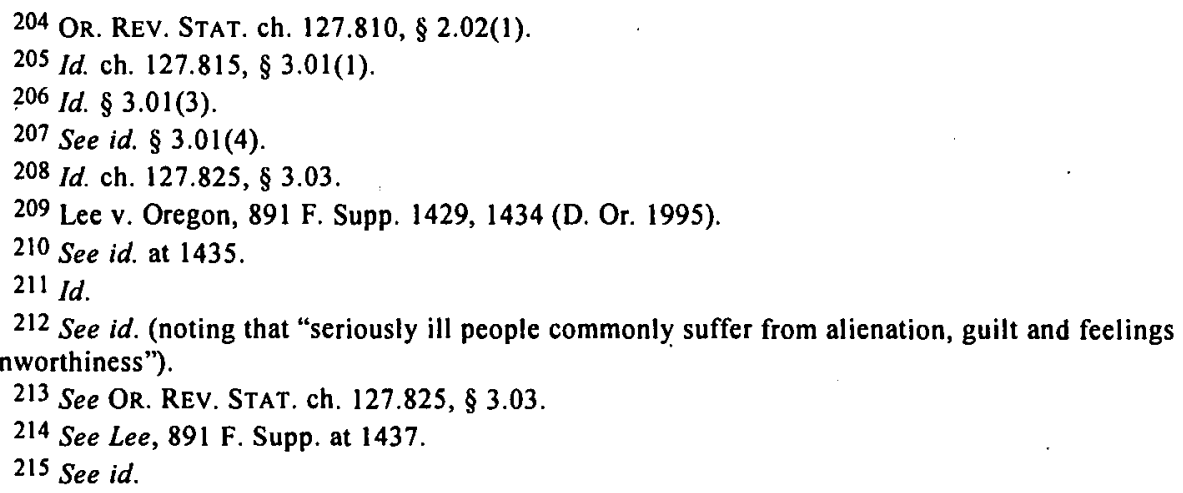


the tiniest fraction of the "terminally ill."216 As the U.S. Supreme Court noted in New York City Transit Authority v. Beazer, "it is of no constitutional significance that the degree of rationality is not as great with respect to certain ill-defined subparts of the classification as it is with respect to the classification as a whole." 217 Given the deferential nature of rational basis review, the court should have upheld Measure 16 against the equal protection challenge.

The Lee v. Oregon opinion suggested an interesting question: whether a more appropriate equal protection analysis would focus on the denial of the right of assisted suicide to citizens of Oregon other than the terminally ill.218 "While the practical effect of a state law may be to create some inequality between particular classes of persons ...., it cannot create an illusory classification where the reasons for the law apply equally to all members of the public."219 If Measure 16 rests on notions of autonomy, then all citizens should enjoy the right to physician-assisted suicide. 220 Of course, this argument could not advance far, given the current state of public opinion today. 221

216 See id. The court only states that "Measure 16 provides a means to commit suicide to a severely overinclusive class who may be competent, incompetent, unduly influenced or abused by others." Id.

217440 U.S. 568, 593 (1979); see also FCC v. Beach Communications, Inc., 113 S. Ct. 2096, 2101 (1993) (holding that a classification "must be upheld against an equal protection challenge if there is any reasonably conceivable state of facts that could provide a rational basis for the classification"); Dandridge v. Williams, 397 U.S. 471, 485 (1970) (holding that state legislation "does not violate the Equal Protection Clause merely because the classifications [it makes] are imperfect").

218 See Lee, 891 F. Supp. at 1438 (suggesting that one of the problems with Measure 16 is its inability to limit "rational suicide" to the hard cases). "The suffering of some competent, terminally ill persons gives rise to compassionate arguments." Id.

219 Id. at 1433 .

220 A response to this argument is that the reasons for Measure 16 do not apply equally to all citizens. Principal interests cited in creating an exception for terminally ill patients under Measure 16 include avoiding "unnecessary pain and suffering," and protecting "the terminally ill and their loved ones from financial hardships." Id. at 1434. Certainly these interests are particular to the class of persons the measure intended to help.

221 Consider an editorial written shortly after Judge Hogan's decision:

Do you suppose that dying Oregonians, fighting the pain of cancer or the indignities of dependency, are relieved to know that a federal judge doesn't want them discriminated against?. . . The ruling is an appalling commentary on the strange twist the discrimination argument has taken. Next thing you know, Oregonians who do not have a terminal disease will claim that the law discriminates against them because they don't have the right to get a doctor to help them die.

Dying and Discrimination: Death with Dignity Case Misconstrues the Issue, PEORIA J. STAR, Aug. 15, 1995, at A4. In Compassion in Dying v. Washington, 49 F.3d 586, 591 (9th Cir. 1995), rev'd, 79 F.3d 790 (9th Cir. 1996), the court derided the possibility:

If at the heart of liberty protected by the Fourteenth Amendment is this uncurtailable ability to believe and to act on one's deepest beliefs about life, the right to suicide and the right to assistance in suicide are the prerogative of at least every sane adult. The attempt to restrict such rights to the terminally ill is illusory. If such liberty exists in this context, ... every man and woman in the United States must enjoy it. . . . The conclusion is a reductio ad absurdum.

Id. 


\section{Whether Measure 16 Violates the Due Process Clause of THE FOURTEENTH AMENDMENT}

Although the district court in Lee declined to address the plaintiff's due process claim, 222 it must receive judicial attention before any law allowing assisted suicide becomes effective. The reviewing court should employ rational basis review for those acts that do not materially impair a fundamental right. ${ }^{223}$ Under rational basis review, a law does not violate due process if the court determines that it rationally relates to a legitimate government interest. 224 The court's disposition of the equal protection challenge demonstrates that Measure 16 implicates no fundamental right. 225 As such, courts generally defer to legislative judgment. 226

The plaintiffs claim that the rights of depressed, terminally ill people "are affected adversely by allowing assisted suicide without creating adequate safeguards to protect them from self-harm."'227 As in the context of equal protection, the state would respond that the law protects such individuals through its process of screening out those thought to be incompetent. However, in Lee, the court found such procedures would not protect the lives of depressed, terminally ill people.228 If swayed by reasoning employed in Lee, the reviewing court would likely declare that Measure 16 violates the due process rights of the incompetent, terminally ill. 229

\section{E. OVERCOMING CONSTITUTIONAL HURDLES By MODIFYING MEASURE 16}

If eventually struck down, Measure 16 should be re-drafted, addressing Judge Hogan's concerns. Changes would alleviate the court's fear that people with treatable depression might receive the lethal medication. First, drafters should add protections to ensure that only truly competent individuals utilize physician-assisted suicide. Judge Hogan noted that Oregon law authorizes the civil commitment of mentally ill persons who endanger themselves in some way. ${ }^{230}$ A treating physician licensed by the Board of Medical Examiners would have the authority to hold individuals in a health care facility until a judge appoints a qualified examiner to evaluate the patient.231 The Lee court also suggested that Measure 16 require that "the person consult a certified social worker or other specialist to explore social

222 See Lee, 891 F. Supp. at 1437.

223 Fundamental rights are those "implicit in the concept of ordered liberty" or "deeply rooted in this Nation's history and tradition." Bowers v. Hardwick, 478 U.S. 186, 191-92 (1986).

224 See, e.g., Kelley v. Johnson, 425 U.S. 238, 248 (1976) (holding that regulations limiting policemen's hair length were reasonable).

225 See supra text accompanying notes 185-92.

226 See, e.g., Kelley, 425 U.S. at 245 (noting that if state regulations survive challenges based on the "explicit language of the First Amendment, there is surely even more room for restrictive regulations of state employees where the claim implicates only the more general contours of the substantive liberty interest protected by the Fourteenth Amendment").

227 Kathy T. Graham, Last Rights: Oregon's New Death with Dignity Act, 31 WILlameTtE L. REV. 601,628 (1995).

228 See Lee v. Oregon, 891 F. Supp. 1429, 1435-37 (D. Or. 1995).

229 But see Graham, supra note 227, at 630 (arguing that if "Oregon voters want to protect these rights, individual plaintiffs should not be allowed to subvert them").

230 See Lee, 891 F. Supp. at 1435; see also OR. REV. STAT. $\$ 426.070(5)$ (b)(A) (1995).

231 See Lee, $891 \mathrm{~F}$. Supp. at 1434. It is not entirely clear in what way a treating physician better serves the goal of assessing a patient's competency than the attending and consulting physicians under Measure 16. Presumably, the treating physician would be more familiar with the patient's condition, and should therefore have some insight into how to judge her decision to die. 
services which might assist the person to live in greater comfort."232 Although this further requirement may temporarily frustrate competent individuals who have decided to die, it may also help to ensure that all those contemplating their options have the information necessary to make an informed choice. A mandatory session with a mental health professional would protect those that attending and consulting physicians might otherwise incorrectly classify as competent.

Another of the court's concerns focused on a physician's duty under Measure 16.233 Although doctors generally must treat patients with the same diligence and expertise as other doctors in similar circumstances, Measure 16 provides immunity to any physician who "participates in good faith . . . with this act."234 This could conceivably allow the physician to "negligently misdiagnose a person's condition and competency and negligently prescribe a drug overdose, so long as those actions are in 'good faith."'235 Removing the good faith provision would bring Measure 16 in line with the accepted standard of care, and should further alleviate the court's concern.

Perhaps the most significant modification suggested by the court's opinion in Lee relates to Measure 16's lack of safeguards at the time the patient ingests the medication. ${ }^{236}$ At that moment, the patient's decision to take the lethal medication must be rational and voluntary. 237 A modified statute could require a physician's attendance at the time the patient takes his or her life. Or it could mandate that the patient take the medication immediately on receipt of the drugs. Either way, the modification would make the Death with Dignity Act more sensitive to curtailing undue influence by third parties. 238

The perceived inadequacies of Measure 16 led the Lee court to conclude that "Measure 16 provides a means to commit suicide to a severely overinclusive class who may be competent, incompetent, unduly influenced, or abused by others."239 By tightening those portions of the statute designed to guarantee that only appropriately trained professionals contribute to the prescription of lethal doses of medication to truly competent persons, courts should no longer find such laws constitutionally deficient. 240

\section{CONCLUSIONS}

It might well turn out that courts will be more willing to uphold the constitutionality of legislation, such as Oregon's, that partially decrim-

232 Id. "With death at issue under Measure 16, the court is unable to conceive of a set of facts under which it would be rational to not require mental and social evaluations by appropriately trained professionals." Id. at 1436.

233 See id. at 1436-37.

234 Death with Dignity Act, OR. REV. STAT, $\$ 127.885$.

235 Lee, 891 F. Supp. at 1437.

236 See id.

237 See id.

238 See id.

239 Id.

240 The argument that Measure 16 denies terminally ill patients equal protection would dissipate if Oregon repealed its statute outlawing assisted suicide. In the absence of that statute, there could be no force to the argument that Measure 16 denies to terminally ill people the same protection afforded to other citizens. This solution appears unlikely due to the historical support of such laws. 
inalizes assisted suicide, if that legislation is narrowly drafted and contains adequate protections, than they are to hold unconstitutional statutes that criminalize assisted suicide. So doing would exhibit the kind of deference to democratic values and to the limited role of the courts-especially when the partial decriminalization legislation is enacted by referendum-that courts almost reflexively invoke when hesitating to hold statutes unconstitutional. 241

The success or failure, both of attempts to legalize physician-assisted suicide and of challenges to laws prohibiting assisted suicide, rests with the U.S. Constitution. Whether one may reasonably argue that a constitutionally protected right to physician-assisted suicide exists (fundamental or otherwise), it seems unlikely that the U.S. Supreme Court would agree to such an interpretation. ${ }^{242}$ Although broad readings of certain judicial opinions suggest that a state's prohibition against assisted suicide may unconstitutionally interfere with the right of privacy, ${ }^{243}$ the Court appears hesitant to supplant that state's judgment.244

In Lee $v$. Oregon, the District Court for the District of Oregon found that Measure 16 violated the Equal Protection Clause of the Fourteenth Amendment.245 The court's analysis was faulty, however, and its decision should be reversed. In fact, the Ninth Circuit Court of Appeals itself said in no uncertain terms that Judge Hogan had "clearly erred" in his "highly irregular" equal protection ruling. 246

Under certain circumstances, Measure 16 would have allowed persons diagnosed with a terminal illness to be prescribed a lethal dose of medication. ${ }^{247}$ Therefore, the terminally ill would receive different treatment than the remainder of Oregon's citizens for whom assisted suicide is a felony. ${ }^{248}$ Treating one class differently than the remainder of the state's population is acceptable if the classification drawn is rationally related to a legitimate state interest. ${ }^{249}$ In this case, the State of Oregon correctly argued that allowing the terminally ill, but not other

241 MEISEL, supra note 82, at 510.

242 See supra Part III.

243 See, e.g., Planned Parenthood of Southeastern Pennsylvania v. Casey, 505 U.S. 833, 851 (1992) (noting that the Court's precedents "have respected the private realm of family life which the state cannot enter," and that "choices central to personal dignity and autonomy, are central to the liberty protected by the Fourteenth Amendment").

244 See Cruzan v. Director, Missouri Dep't of Health, 497 U.S. 261, 280 (1990) (stating that a state "is [not] required to remain neutral in the face of an informed and voluntary decision by a physically able adult to starve to death"); see also Casey, 505 U.S. at 851 ("Beliefs about these matters could not define the attributes of personhood were they formed under compulsion of the state.").

245 Lee v. Oregon, 891 F. Supp. 1429, 1437 (D. Or. 1995).

246 Compassion in Dying v. Washington, 79 F.3d 790, 838 nn.138-39 (9th Cir. 1996).

247 See OR. REV. STAT. $\$ 127.805$ (1995).

248 See id. $\$ 163.125(1)(\mathrm{b})$.

249 See Schweiker v. Wilson, 450 U.S. 221, 238-39 (1981) (holding that Congress could make a distinction between residents in public institutions receiving Medicaid funds for their care and residents in such institutions not receiving such funds); New Orleans v. Dukes, 427 U.S. 297, 303 (1976) (holding that unless a classification tramples on "fundamental personal" rights or is drawn on "inherently suspect distinctions such as race, religion, or alienage," the Court will presume the constitutionality of the statutory discrimination and "require only that the classification challenged be rationally related to a legitimate state interest"). 
citizens, to receive lethal doses of medication rationally relates to its interest in, among other things, avoiding unnecessary pain and suffering. 250

Should the courts strike down Measure 16, modifications to the Death with Dignity Act might allow it to withstand the constitutional scrutiny it would surely receive if passed again. The court's ruling noted problems with the determination of whether a person requesting the prescription was really competent. 251 A tighter system which requires evaluation by a mental health professional should satisfy the court's objections.

It appears a challenge to Measure 16 on the grounds that it violates due process would fail under traditional constitutional analysis. In light of the court's reasoning on the equal protection issue, however, a reviewing court might find the law unconstitutional on due process grounds as well. Still, suggested modifications which would satisfy the court's objections with respect to the equal protection violations would probably suffice to eliminate the due process concerns.

250 See Lee, 891 F. Supp. at 1434.

251 See id. (noting that the procedures designed to differentiate between competent and incompetent persons are insufficient). 